\title{
The Importance and Influence of Destination Advertising
}

\author{
By Andrea Csapó-Horváth ${ }^{1}$
}

\begin{abstract}
The tourism industry has become a kingpin industry worldwide. The high proportion of individual travel demonstrates the need for effective advertising. In particular, there is a need to focus not so much on what motivates people to travel, but rather to influence their choice of destination. Tourism advertising, especially destination advertising, an under-investigated field of research, seems to play a significant role in influencing consumers such as future tourists. This paper explores the question of whether Hungarian university students are influenced by destination advertising when choosing their destinations. Using a questionnaire $(\mathrm{N}=125)$, this study examines the question of which advertising elements have the most significant impact on the students.

Furthermore, the paper aims to find answers to these questions: How influential are media channels within the context of destination choice? Is it the language or the image which plays a crucial role in the transmission of the advertisement's message? What might be the essential elements in the actual language used in destination advertising? The research will shed light on which particular linguistic devices increase the impact of the advertisements and which of these devices can be adapted to the Hungarian context.
\end{abstract}

Keywords: destination advertising, questionnaire survey, linguistic devices, effective advertising

\section{Introduction}

In the world economy, the travel and tourism industry has become a leading sector. Nowadays practically everybody in developed countries can be considered a potential tourist. When travelling abroad, according to the Lasswell formula (Róka, 2002), the destination is first selected: where (e.g. Italy), for what purpose (e.g. business trip), how (e.g. airplane), when (e.g. high season), how long (e.g. a week) we travel. The range of questions can broaden, but the destination is usually the primary consideration, with destination advertising playing a crucial role. The high proportion of individual travel demonstrates the need for efficient advertising. It is not so much about motivating oneself to travel as it is about influencing the choice of the destination. Tourism advertising, especially destination advertising which is an under-investigated field of research, seems to play a significant role in influencing consumers such as future tourists. According to Held (2008, p. 150) the specific, distinguished world of text called "advertisement of tourism" does not only spans the whole globe but also, at the same time, makes it into the topic of advertisements.

This paper explores the question of whether Hungarian university students are influenced by destination advertising when choosing their destinations. The first part of the paper gives an overview of tourism advertising, including destination advertising, as well as the language of destination advertising from a linguistic point of view. Advertising is the 
subject of the present study, so it is worth highlighting some characteristics of tourism advertisements. This paper focuses primarily on destination advertisements. From the view of the author, it is necessary to place the language of advertisements under a magnifier, too. Tourism advertisement is an under-explored area in linguistic research; few people have dealt with tourism advertisements analysis thus far.

The second part examines these questions: which advertising elements have the most significant impact on the students; what might be the essential elements in the actual language used in destination advertising; which particular linguistic devices increase the impact of the advertisements.

The data was obtained from a questionnaire survey completed by students of Széchenyi István University, Győr, Hungary.

\section{About the phenomenon of tourism advertising}

Advertising is, without a doubt, the traditional marketing tool in tourism. Tourism advertising is not only used to "sell" goods and services but also "sell" an entire town, region or country. However, tourism advertising also advertises cultural things such as art, historical events, sport, and health. The basic principles of advertising defined by Sowinski (1998) also apply to tourism advertising and these include conspicuousness, originality, and informativeness. According to Schönemann (1989, p. 11), tourism advertising is a means of influencing people to "induce them to make a temporary voluntary change of place using tourist facilities".

However, due to the nature of the tourist product, tourism advertising differs considerably from other forms of advertising. For example, the tourist product cannot be viewed on the shelves of the warehouse, it cannot be inspected at the moment of purchase and consumers' high expectations are closely linked to a relatively high degree of unpredictability. Besides, "high-quality products are also variable due to their concrete dependence on immaterial factors such as landscape, climate, culture or hospitality as well as tourist services and is subject to an evaluation of subjective perception." (Deutsches Seminar Für Fremdenverkehr 1993, p. 6).

\subsection{Characteristics of destination advertising}

Destination advertising is the most important type of tourism advertising. The text type of this kind of advertising has the task of launching a space that incorporates countries, regions, and places as a potential holiday destination in the consciousness of as broad an audience as possible (Held, 2008). In contrast to product advertising, this form of advertising, known as space-packaging in the tourist jargon, offers not a material but a conceptual value. It can be interpreted on two levels according to the value system of our society: on the one hand, it positions a tourist destination and, on the other hand, promotes holidays, which are still the essential component of modern-day lifestyle and the most significant "slice" of leisure services. A classic part of the advertising of tourist areas is the representation of the natural world, of socio-cultural attractions or both which are not only presented as idealised images of the region but also aim to manipulate the individuals' emotions. A destination advertisement is a suggestive-emotional advertisement, in which the most commonly discovered elements are enjoyment, experience, proximity to nature, and freedom. According to Sas (2007, p. 311), "in our age, emotions have taken the place 
of facts and truths." It is not enough for the tourist destination to try to attract potential tourists with its attractions, it must also convey an emotional added value that is characteristic of that particular destination, and not of any other (cf. Fleischmann, 2004). The USP (unique selling proposition) is increasingly being replaced by the UPP (unique perception proposition) (Deutsches Seminar für Fremdenverkehr, 1993), the exceptional attraction value of the product. Attractiveness connects with the world of feelings, desires, and subconscious. Destination advertising is less about information; it is imaginative, it is "above all a skilful image promotion" (Held, 2019, p. 149). "The strategies of destination advertising focus above all on the visual-sensory awakening of illusions, longings, and desires, and thus try to transport the propagated space to the dream with all available means" (Held, 2008, p. 152). To sum up, this type of advertisement is meant to convert dreams into action, that is to get the potential tourist "to transform his positional energies into kinetic energy" (Ogilvy, 2008, p. 155).

\section{The language of destination advertising from a linguistic point of view}

There is a gap in the research concerning the examination of destination advertisements from a linguistic viewpoint. The language of destination advertising has the particular function of advertising for a trip or the use of a service. However, as Römer (1973) points out, it has unique linguistic characteristics. It uses many possibilities to attract attention, which is manifested in language use and appears on all linguistic levels: lexical, semantic, pragmatic, morphological, syntactical and stylistic.

Advertising language draws from everyday language. It is lifelike and conveys the message briefly and concisely. It also makes use of other language varieties such as dialects, technical jargons, or youth language to address suitable target groups and evoke certain associations (cf. Janich, 2013). Advertising language at the word level (predominantly nouns, superlatives, relatively few verbs, frequent neologisms, foreign words, etc.), at the sentence level (imperative sentences, frequent occurrence of incomplete sentences, etc.), and at the textual level (persuasion, "misuse" of grammar rules, etc.) exhibits language features that are typical in advertising (Csapó-Horváth, 2011).

Concerning lexis, the use of foreign words plays a crucial role in tourism advertising. Schütte (1996) thinks that this phenomenon is related to the degree of novelty of advertising: the later the advertisement is created, the higher is the presence of English in it. The pre-mash of Anglicisms is comprehensible in German as well as in Hungarian ads and examples of this include 'event', 'shopping', 'highlight'. The English expression is considered a real eye-catcher, which stimulates the recipient to read on. In destination advertising, English is followed by French then by Italian and Spanish as the main languages used. The essence lies in "the foreign" because the strangeness attracts attention; it signals modernity and internationality. In addition, the advertisements also often contain neologisms, predominantly ad hoc formations. Copywriters use any means to attract the attention of the recipient by creating eye-catching, even astonishing words/phrases. Furthermore, phraseologisms, idiomatic phrases and their modifications are a sought-after medium for advertisers. Modifications attract the reader's attention: he searches for the correct form, feels confirmed about the personal knowledge horizon and connects this positive feeling with the advertised destination. Moreover, the language of advertising is rich in nouns and adjectives. The adjectives often appear in the headlines in the 
comparative and superlative form. Not only do they have the function of assigning positive characteristics to the products such as the destination, but they also compare, explicitly or implicitly, the product or service with the same ones of the competition.

As far as syntax is concerned, Römer's (1973, p. 164) comment that "The language of advertising prefers simple and short sentences" still applies today. The copywriters keep the brevity in mind; the ellipses act as "appetisers" for the reader.

Various linguistic and stylistic elements that influence the recipient are also popular, i.e., the shapes that the copywriter (the creative) prefers to achieve the desired effect. The different rhetorical figures, such as personification, parallelism, alliteration, antithesis, rhetorical question, metaphor, hyperbola, anaphor, assonance, climax, etc., guarantee the desired eye-catching effect, increase memorability, promote memorability and contribute to persuasion.

\section{Purpose and methods of the research}

\subsection{Context}

Széchenyi István University is located in Győr, a major city in the North-West of Hungary.

It is a medium-sized university with approximately 14,000 students. The university has nine faculties working in various research fields and four doctoral schools. Eight faculties are located in Győr, and one in Mosonmagyaróvár (a town about $40 \mathrm{~km}$ away). The university provides training leading to $\mathrm{BA} / \mathrm{BSc}$, MA/MSc as well as $\mathrm{PhD}$ degrees. Furthermore, it offers post-graduate courses and carries out research, provides consultancy and other professional activities. Over 25\% of the 100 academic programmes on offer are delivered in English. Széchenyi István University is the largest educational institution in the Northwest region of Hungary.

\subsection{Research aim, participiants and data collection}

The aim of the research is the investigation of the importance and influence of destination advertising. The author hypothesised the following: that destination advertising plays a crucial role in the choice of destination; that according to the students, the language is still the dominant feature in adverts; that linguistic elements are of more importance than visual, non-verbal representations such as graphics or photographs.

The author conducted a questionnaire survey as it is a quick way of obtaining information about individual opinions and experiences of the respondents. In spring 2019 the questionnaire was completed by university students of Széchenyi István University by second and third year BA/BSc students; the responses were anonymous. The students were all aged between 19 and 25 years and studied the same subjects at the same degree course. Therefore the participants were a relatively homogeneous group of respondents in terms of research. The total number of respondents was 125, 113 women and 12 men. The questionnaire was distributed in a printed form given directly to the students. It primarily contains closed-ended questions with 4 or 5 variables, but there is also one openended question. In total, the questionnaire contains 10 items. The questionnaire had multiple choice questions with an added "other" answer option. The possibility of taking a neutral position through response options such as "no opinion", "do not know" and 
"no response", was not given. The last question was an open-ended question asking people to produce their destination advertisements.

This research sought to address the following questions:

1. How often do you go on longer or shorter holiday trips (both at home and abroad)?

2. What or who influences your choices of travel destination?

3. Which media channels' destination advertisements have the best effect on you?

4. In which language do you generally see (read) the destination advertisements?

5 . What impresses you most in destination advertisements?

6. Do you think advertising text is necessary?

7. Foreign words often appear in ads, primarily anglicisms. Are you disturbed by them in understanding advertisements?

8. What do you consider particularly crucial in destination advertising?

9. What are, from your point of view, the essential elements in the actual language used in destination advertising?

10. Choose a destination and produce an advertisement which advertises this destination. Which advertising elements appear in your ad?

\subsection{Data analyses}

Responses to the closed-ended questions were summarized, and the resulting numbers were converted into percentages. Questionnaire data coming from the last openended question:-“Choose a destination and produce an advertisement which advertises this destination. Which advertising elements appear in your ad?” were grouped into thematic categories.

\section{Findings}

It is important to note that since the number of men who answered the questionnaire was small, barely $1 \%$ of the total number of respondents, the researcher did not consider gender to be a variable of any significance when evaluating the questions.

The answers to the first question, concerning the frequency of vacation trips, confirm that university students (generation $\mathrm{Y}$ and $\mathrm{Z}$ ) like to travel. More than half of the respondents $(59 \%)$ travel at least three times or more than three times a year both at home and abroad. $34 \%$ of the students have a vacation once a year, and 3\% twice. Only three people replied that they do not take any holidays at all. Although not all respondents marked whether they are going on holiday at home or abroad, it is fair to conclude that they are thinking of a holiday abroad.

The second question examined the influence of advertisements when choosing a destination. Although the students look at the ads, 30\% do not pay attention to them. It is possible not to engage in advertising consciously, but it is also clear that we encounter advertising daily, and it is quite hard to avoid its effects. A total of $21 \%$ of the respondents replied that advertisements influenced them when choosing their travel destination. For almost half of the students $(49 \%)$ friends, acquaintances and relatives are influential factors when deciding on their vacation.

In the next question the author wanted to investigate which advertising media young people prefer. As expected, except for eight people, everyone identified the Internet as 
their primary advertising medium. Although the use of the Internet has increased considerably, mass media advertising is still in use. $22 \%$ of university students read printed advertisements such as advertisements published in magazines, tourist offices' brochures and flyers. Barely 10\% of those surveyed mentioned television as an advertising medium where they watch destination advertisements. This low percentage might be related to a change in TV viewing habits, as these generations prefer to use the Internet. Only a small percentage of the respondents (7 people) did not mark a single advertising medium. According to them, they are not influenced by any advertising media.

The fourth question asked about the language the students read the advertisement in. Almost half of the respondents (49\%) only look at ads in Hungarian. It is particularly pleasing that only three fewer people, i.e. $47 \%$ of respondents, read destination advertisements in English. As far as German advertising is concerned, the result is stunning: only eight students replied that they understand ads in German. Only a few have noticed that they are engaged in reading advertising in other languages, such as Spanish, Slovak, and Czech.

Among commercial researchers it is still a controversial question whether it is the language or the image which plays a crucial role in the transmission of the message of the advertisement. It can be deduced from the answers of the fifth question, that the visual elements are the most important feature, that is a striking image has the most significant influence on $58 \%$ of young adults surveyed. The headline and the efficient body text appeals to $27 \%$ of the respondents. $36 \%$ of the students say that both the picture and the text impress them. 18\% mentioned that striking, humorous, and unusual elements of the advertisements exert a significant influence on them. The answers confirm that visuality is characteristic of destination advertising.

The responses given for the question "Do you think the advertising text is necessary?" seem to be in direct contradiction to the answers to the fifth question. More than half of the students pointed out that visual elements influence them most of all, but, according to only $10 \%$ the picture is sufficient in an advertisement. $48 \%$ of respondents emphasise that the text contains the necessary information. Almost the same percentage $(42 \%)$ highlighted that they read the ad if the headline aroused their interest.

The seventh question aimed to find out whether the participants are disturbed by foreign words and anglicisms in their understanding of advertising. According to $45 \%$ of the students, both foreign words and anglicism belong to advertisements, and another $29 \%$ believe that foreign words make ads; they are necessary. $18 \%$ of the respondents make no effort to understand everything; they are satisfied with what they can make sense of. A few students $(9 \%)$ expressed their disapproval of the foreign words, which is rather hard to understand in the light of their age and previous education.

The next question demonstrated what young people believe is vital in destination advertising. Based on the answers, the advertisements should be informative (77\%), creative $(72 \%)$, jocular and colourful $(61 \%)$, humorous $(21 \%)$, and they have to appeal to emotions $(15 \%)$.

In an advertisement, not only the content, but also the form is an essential element. The ninth question asked about wording. Most students $(70 \%)$ believe that the most important thing is that there are short, concise phrases in advertisements. According to $55 \%$ of them, ads should be understandable from at first sight so one should not have 
to think about it for long. Relatively few $(19 \%)$ believe that puns or unusual phrases make advertising more attractive. Only six people want advertisements to work as an enigma. The closing task aimed to examine whether the answers given in the close-ended questions appear explicitly in the advertisements written by the students, or to what extent they can put what is written into practice in a specific task. The author also wanted to know how popular the domestic destinations are with the participants, or whether they identify a holiday with a trip abroad. It was interesting to see what they would value if they were the advertising experts. $73 \%$ of the respondents accomplished the task. However, $27 \%$ did not answer. Seven people did not name any destinations, and they only summed up how the top advertisement looked like. They concluded that a great advertisement is colourful, creative, sparks interest, affects one's feelings and consists of both pictures and a headline. The other 84 people chose a specific destination and tried to advertise it. The assumption that vacation equates to travelling abroad was confirmed. $77 \%$ of young people ( 70 people) preferred to travel abroad and chose active tourism. 42 people are attracted by a certain city such as London, Barcelona, Prague, Berlin or by the sights of a country such as Spain, Italy or Turkey. Passive tourism, for example, relaxing on the beach, attract 28 people. Concerning domestic destinations, it was expected, that "the Hungarian sea" would top the list, but cultural tourism and recreational tourism appear in equal proportions.

\section{Discussion}

According to WYSE Travel Confederation's analysis, youth travel (Generation Y and Z) has become one of the fastest-growing segments of international tourism, accounting for more than twenty-three per cent of over one billion travellers per year (Süli et al., 2019). In the next few years, these two generations, i.e., generation $\mathrm{Y}$ and $\mathrm{Z}$, will probably actively shape tourism. According to Süli et al. (2019, p. 24), "they are the travellers of the future". This study has supported that students enjoy travelling; $97.6 \%$ of the respondents enjoy taking a vacation at least once a year. However, the majority $(77 \%)$ of students prefer to holiday abroad. This gives us reason to speculate why domestic tourism has taken a back seat although Hungary is rich in sights, in beautiful landscapes. In other words, Hungary is full of treasures. Arguably, the target group should be explicitly addressed, and the destinations better positioned. The role of tourism marketing, in this case, is undeniable.

The present study was designed to determine the effect and influence of destination advertisements. This research has shown that destination advertising is less influential than expected in destination selection, at least for generation $\mathrm{Y}$ and especially generation $\mathrm{Z}$. Although students look at advertisements, less than a quarter of respondents take them into account when making a decision. When choosing a destination, the opinion of acquaintances, relatives and friends is the primary determinant. There was no investigation into whether, when trying to influence these potential tourists, the friends/relatives/ acquaintances rely exclusively on their own experiences when proposing a destination or whether they themselves have been influenced by a creative, attention-grabbing advert they have seen some time, somewhere.

Especially Gen Z, often labelled as "digital natives" are very active on the social media; they grew up with the new technology of the digital age when they were young. Computer 
games, e-mails, the Internet, mobile phones, and instant messaging are integral parts of their lives, and they were socialised with them early on. As Medić (2018, p. 450) writes, "Social networks (Facebook, TripAdvisor, Foursquare, YouTube, Instagram, Pinterest, Twitter, LinkedIn and others), web sites, e-mails, mobile apps, and search engines are increasingly being used for the purpose of advertising and informing customers, consumers, and users". The findings have confirmed that the future of advertising is the online world; $94 \%$ of the respondents prefer online destination advertisements. It was also shown that the respondents read destination advertisements in both Hungarian and English by roughly the same amount. Nowadays, English is the lingua franca, so it is understandable that among foreign language advertisements, the English rating takes first place. Both the headline and the body text as well, often imply an enigma or a puzzle; the implicit coding of the information is typical. Headlines and body texts of this type make one think more and require more mental activity and creativity from the recipient which is so much easier in the mother tongue. It explains why almost half of the respondents prefer advertisements in Hungarian.

More than half of the students are initially impressed by the eye-catching pictorial elements in adverts. However, the advertising text is also important to them in the sense that if concrete wording is used, it helps the respondents imagine the advertised destination better. In the case of destination advertising, the image design is in many cases almost identical with or at least very similar to each other, and the landscapes could even be interchangeable in many destination advertisements. It is the language that gives the real meaning to the obscure, polysemantic images of a given target area. Thus, the responses point out that in destination advertisements, the image and the text are of about equal value. As the headline and the picture complement each other, both the text and the image are indispensable elements of tourism commercials. From this point of view, the results do not appear to support the author's hypothesis that language has kept its dominance in advertising. According to Schierl (2001, p. 251) "The picture and the text make out a super sign which carries the meaning of the message one wishes to transmit."

Nowadays people get ready-made information everywhere and young people expect the same from destination advertising. For the majority of respondents, advertising should communicate information. The respondents want to know as much as possible about the given destination before choosing it; an attractive picture is not enough. What is crucial for them is that there are explicit phrases, so that they do not have to think much. The desired destination advertising should be short and to the point.

Three quarters (74\%) of respondents believe that foreign words, such as anglicisms, are part of advertising. It can be explained by the fact that foreign words, primarily anglicism, are not foreign to everyday language or advertising language. Advertising experts often use anglicisms to achieve a strange effect, and English is very flexible and adaptable. Anglicisms and in general, foreign words catch attention and serve as image formulations. The research identifies some linguistic tools which increase the effectiveness of advertisements, tools which can be adapted to Hungarian conditions and incorporated into the marketing communication of the industry. This approach agrees with Süli et. al's (2019) point about how important it is for the industry to learn about young people's experiences. They write, "getting to know the decision-making mechanisms of young people and their opinions about various destinations can serve as a lesson for tourism 
providers, as these trends, combined with them, can fundamentally influence future trends in tourism" (Süli et al., 2019, p. 20).

\section{Conclusions}

The author believes that advertising is unavoidable and it is self-evident that it works. The question is how to bring advertising closer to the recipient, how to increase the impact of advertising, which advertising elements should be used to convince the recipients, in this case, the potential tourists, to buy the product.

This research has certain limitations related to the relatively small number of participants. In the future, the research should be extended to incorporate a broader target group. Analysis of the given information will serve as the basis for a following detailed study because this research has raised many questions which further investigation could answer.

In recent years, there has been an increasing interest in ecotourism, soft tourism and sustainable tourism. Tourism industry nowadays understands that environmental issues influence the travel decisions of tourists. Accordingly, concepts such as ecotourism or sustainable tourism have been developed. Many tourists want an intact environment and authentic cultural experiences because they set out on a journey because of their interest in natural and cultural assets. The vacation should be eventful and exciting without disturbing the nature. There are more and more destinations in the world that have become famous for sustainable tourism where the main attractions are the untouched nature and cultures. Ecotourism is also becoming increasingly popular in Hungary such as the ten national parks with their flora and fauna or their rich nature trails. The author intends to conduct further research to determine whether new types of tourism such as ecotourism or sustainable tourism, appeal to young people, especially to the representatives of generations $\mathrm{Y}$ and $\mathrm{Z}$. It would be interesting to know if they are motivated by sustainability when choosing a destination. The extent to which sustainability appears in destination advertising is also an exciting topic. Thus, this study serves as a basis for future explorations, particularly for a more in-depth analysis of this topic.

\section{Acknowledgements}

The research reported in the study was carried out with the support of the project called "Internationalisation, initiatives to establish a new source of researchers and graduates, and development of knowledge and technology transfer as instruments of intelligent specialisations at Széchenyi István University, Hungary”, EFOP-3.6.1-16-201600017.

\section{References}

Csapó-Horváth, A. 2011. Werbung und Werbesprache. ORBIS LINGUARUM, Vol. 37, 341-351.

Deutsches Seminar Für Fremdenverkehr (1993). Werbung unter Druck. Berlin

Fleischmann, K. 2004. Touristische Bilderwelten: Zur Produktion von „Weltansichten“ durch Tourismuswerbung. In: Tourismus Journal. 8. Jg. Heft 3. 419-434. 
Held, G. 2008. „Der Raum als Traum - intersemiotische Gestaltungsstrategien und ihre Realisierung in globalen Kampagnen der Tourismuswerbung". In: Held, G./Bendel, S. (Hgg.): Werbung grenzenlos. Frankfurt am Main: Peter Lang, 149-172.

Held, G. 2019. Destinationswerbung. Zur Image-Konstruktion von touristischen Räumen durch multimodale Inszenierung von Identitätsmarkern. Zeitschrift für Tourismuswissenschaft Vol.11 No.1 pp.149173

Janich, N. 2013. Werbesprache. Ein Arbeitsbuch. 3. Auflage. Tübingen: Gunter Narr

Medić, M. and Jacoby, I. 2018. New Trends in Advertising on the Basis of Tourism Development In: Csapó, J. (et al.) Generációk a turizmusban. I. Nemzetközi Turizmusmarketing Konferencia: Tanulmánykötet. Pécs, Magyarország : Pécsi Tudományegyetem Közgazdaságtudományi Kar pp. 449-456.

Ogilvy, D. 2008. Egy reklámszakember vallomásai. 2. Kiadás. Budapest: Park Kiadó

Róka, J. 2002. Kommunikációtan. Budapest: Századvég Kiadó

Römer, R. 1973. Die Sprache der Anzeigenwerbung. 3. Auflage. Düsseldorf: Schwann

Sas, I. 2007. Reklám és pszichológia. Budapest: Kommunikációs Akadémia

Sowinski, B. 1998. Werbung. Tübingen: Niemeyer

Süli D., Tóth B., Nagy Gy. and Martyin - Csamangó Z. 2019. Az utazással kapcsolatos attitűdök és vélemények Magyarországról mint turisztikai desztinációról az Y és Z generáció körében In: Csapó, J. (et al.) Turizmus, Fogyasztás, Generációk. II. Nemzetközi Turizmusmarketing Konferencia: Tanulmánykötet. Pécs, Magyarország : Pécsi Tudományegyetem Közgazdaságtudományi Kar pp. 20-35.

Schierl, T. 2001. Text und Bild in der Werbung. Bedingungen, Wirkungen und Anwendungen bei Anzeigen und Plakaten. Köln: Herbert von Halem Verlag

Schönemann, K. 1989. Werbung im Tourismus-Marketing. Landesfremdenverkehrsband Bayern e.V. München

Schütte, D. 1996. Das schöne Fremde. Angloamerikanische Enflüsse auf die Sprache der deutschen Zeitschriftenwerbung. Opladen: Westdeutscher Verlag 